\title{
ANTIOXIDANT AND CYTOTOXIC ACTIVITY OF COMBINED EXTRACTS PREPARED USING FICUS RELIGIOSA AND FICUS BENGHALENSIS LEAVES AGAINST CERVICAL CANCER CELL LINE (HELA)
}

\author{
SURIYA KUMARESAN, REMA RAMASAMY, PHILIP ROBINSON JAYACHANDRAN*
}

Department of Biotechnology, K. S. Rangasamy College of Technology, Tiruchengode, Tamil Nadu, India. Email: philiprobin81@gmail.com Received: 08 May 2018, Revised and Accepted: 10 August 2018

\section{ABSTRACT}

Objectives: Medicinal plants and herbs are used in combination in Ayurveda and folklore medicine as they exhibit good cytotoxic activity. In the present study, the antioxidant, phytochemical, and cell proliferation activity of the combined crude methanolic extract of Ficus religiosa and Ficus benghalensis leaves were investigated.

Methods: Antioxidant activity was performed by 2, 2-diphenyl-1-picryl-hydrazyl-hydrate (DPPH) and hydrogen peroxide methods, and the presence of the phytochemicals was screened using the gas chromatography-mass spectrometry. The extract was further evaluated for its cell proliferation activity against cancer cells using the mitochondrial reduction assay. Antioxidant property of the extracts was measured using the DPPH, hydrogen peroxide, and ferric-reducing antioxidant power assay, respectively, using the UV spectrophotometer.

Results: The combined extract exhibited strong antioxidant potential in DPPH assay by increase in the percentage of inhibition with the increase in concentration. Similarly, the $\mathrm{IC}_{50}$ value of the methanol extract in peroxidase scavenging activity was $49.85 \mu \mathrm{g} / \mathrm{mL}$ comparatively lower than the ascorbic acid used as standard. The phytochemical analysis of the methanol extract showed the presence of nine phytoconstituents, which exhibit antioxidant and anticancer property. Mitochondrial reduction assay performed to evaluate the cell proliferation activity of the combined leave extract showed that increase in the concentration of the extract decreased the cell proliferation in the HeLa cell line.

Conclusion: The results of present study show a possible synergistic activity of leaves against human cervical cancer.

Keywords: Antioxidant, Phytoconstituents, Cytotoxicity, HeLa cell line, MTT assay.

(c) 2018 The Authors. Published by Innovare Academic Sciences Pvt Ltd. This is an open access article under the CC BY license (http://creativecommons. org/licenses/by/4. 0/) DOI: http://dx.doi.org/10.22159/ajpcr.2018.v11i12.26948

\section{INTRODUCTION}

Among women population worldwide, cervical cancer is one of the leading causes of death due to malignant tumors. The young, adulthood to middle age women are diagnosed with cervical cancer, and the average age for diagnosis approximately is 40 years. Recently, the incidence of cervical cancer is increasing in young women. Medicinal plants are used for the treatment of cancer [1]. The treatments of many types of cancers using herbal medicines are substantiated in the literature $[2,3]$. The activity of the polyphenols of plants in inhibiting the process of carcinogenesis is studied in several models [4]. The antioxidative and possible anticarcinogenic activities of phytochemical compounds from traditional and folklore medicines have gained momentum in designing drugs against cancer [5]. The presence of flavonoids and other phenolic compounds from fruits has suppressed the growth of various cancer cells by inducing apoptosis [6,7]. Vitamins, pigments, phenolic lactones, flavonoids, tannins, and alkaloids are the major metabolites of the plants that exhibit unique properties to treat various diseases [8]. In comparison with standard treatments, the medicinal plants are relatively safe treatment, easily accessible, and cost-effective [9]. Ficus species are widely used in the management of various types of diseases such as respiratory disorders, sexual disorders, and central nervous system disorders, cardiovascular disorders, gastric problems, skin infections, and diabetes.

Ficus benghalensis is a member of four sacred trees, the bark and leaves of the tree are used in the treatment of skin disease, anti-inflammatory, antiseptic, dysentery, ulcers, vaginal disorders, leukorrhea, menorrhagia, and deficient lactation [10]. Ficus religiosa has many medicinal properties and the leaves have the important medicinal property of antivenom activity and it regulates the menstrual cycle in women [11]. It is used in the treatment of cancer and inflammation or infectious disease in Bangladesh [12]. The combination of leaves of F. religiosa and F. benghalensis has been suggested in folklore medicine for post-maternal recovery in women to overcome the problems of bacterial infection and for speedy recovery from wounds caused in vaginal region. Hence, in the current study, the leaves of both the plants were used to screen their antioxidant potential and anticancer activity against cervical cancer.

\section{METHODS}

\section{Collection of sample}

The leaves of $F$. religiosa and F. benghalensis were collected from Cherupushpam Pharma, Mala, Thrissur, Kerala, India. The collected leaves were washed in sterile water and shade dried. The dried leaves were then powdered in a commercial blender. About $10 \mathrm{~g}$ of the powdered leaves was weighed and dissolved in $100 \mathrm{~mL}$ of methanol. The dissolved powder was kept in a shaker for extraction up to $8 \mathrm{~h}$ at room temperature and then filtered. The filtrate was dried in hot air oven at $60^{\circ} \mathrm{C}$, and the extract was stored at $4^{\circ} \mathrm{C}$ until further use.

\section{Preparation of extract}

Collected leave samples were surface sterilized with tween 80 and shade dried. The dried leaves were powdered in blender. $10 \mathrm{~g}$ of the leaves powder was weighed and dissolved in $100 \mathrm{~mL}$ of methanol. The dissolved sample was kept in shaker speed of $140 \mathrm{rev} / \mathrm{min}$ at room temperature for $24 \mathrm{~h}$ and filtered. The filtrate was collected and was condensed in a rotatory evaporator under reduced pressure to dryness at $50^{\circ} \mathrm{C}$ with $180 \mathrm{rpm}$. The extract collected was kept at $4^{\circ} \mathrm{C}$ until further use. 


\section{Antioxidant assay}

Antioxidant potential of the extract was evaluated using the ferricreducing antioxidant power assay, 2, 2-diphenyl-1-picryl-hydrazylhydrate (DPPH) assay, and hydrogen peroxide assay according to the standard methods with the different concentrations of $20 \mu \mathrm{g} / \mathrm{mL}$, $40 \mu \mathrm{g} / \mathrm{mL}, 60 \mu \mathrm{g} / \mathrm{mL}, 80 \mu \mathrm{g} / \mathrm{mL}$, and $100 \mu \mathrm{g} / \mathrm{mL}$

\section{DPPH radical scavenging activity}

Free radical scavenging activity of the plant material was determined using DPPH. The antioxidant assay was performed based on Ochuko et al., 2012, with some modification, $1 \mathrm{mg}$ of the concentrated extract was dissolved in $1 \mathrm{~mL}$ of the solvent (methanol). $0.1 \mathrm{mM}$ of DPPH was prepared fresh before use. Different concentrations of the plant extract were taken, and the volume was made up to $1 \mathrm{~mL}$ using the DPPH solution and incubated in dark for $30 \mathrm{~min}$ at room temperature. The absorbance was measured at $517 \mathrm{~nm}$ in UV spectrophotometer (Tailor and Goyal, 2014). The $\mathrm{IC}_{50}$ value of the sample was calculated based on the absorbance. The percentage of inhibition was calculated using the formula,

DPPH scavenging effect $(\%)$ or percent inhibition $=$ (absorbance of sample-absorbance of blank)/absorbance of control $\times 100$

\section{Hydrogen peroxide assay}

Hydrogen peroxide (40 mM) was prepared in phosphate buffer saline ( $\mathrm{pH}$ 7.4). The plant extracts at different concentrations were taken in separate tubes and the total volume was made up to $3 \mathrm{~mL}$ with $\mathrm{H}_{2} \mathrm{O}_{2}$ solution. The resulting solution was incubated at room temperature for $10 \mathrm{~min}$ and absorbance was recorded at $230 \mathrm{~nm}$ in UV spectrophotometer (Gill et al., 2010). Sodium phosphate buffer solution without $\mathrm{H}_{2} \mathrm{O}_{2}$ served as blank. The $\mathrm{H}_{2} \mathrm{O}_{2}$ scavenging activity of the plant extract was calculated using the formula,

Percentage scavenging of hydrogen peroxide $=\left[\left(\mathrm{A}_{\text {control }}-\mathrm{A}_{\text {sample }}\right) / \mathrm{A}_{\text {control }}\right]$ $\times 100$

\section{Gas chromatography-mass spectrometry (GC-MS) analysis}

The phytochemical compounds present in the combined methanol extract of $F$. religiosa and $F$. benghalensis were identified using GC-MS technique using Clarus 680 GC system, ultra high pure helium (99.99\%) was used as carrier gas with flow rate of $1 \mathrm{ml} / \mathrm{min}$. The injection, ion source temperatures are maintained at $260^{\circ} \mathrm{C}$. The ionizing energy was $70 \mathrm{eV}$. The oven temperature is programmed from $60^{\circ} \mathrm{C}$ (hold for $2 \mathrm{~min}$ ) to $300^{\circ} \mathrm{C}$ at a rate of $10^{\circ} \mathrm{C} / \mathrm{min}$. The combined crude methanolic extract of $F$. religiosa and $F$. benghalensis was diluted with methanol $(1 / 100, v / v)$ and filtered. The particle-free extract was injected in syringe and injected into injector with a split ratio of 10:1. All the data were obtained using the mass spectra with scan range of 50-600 Da. The percentage composition of the crude extract was based on the GC retention time. The mass spectra were computer matched with those of standard available in mass spectrum libraries.

\section{Cervical cancer cell line}

Human cervical cancer cell line (HeLa) was procured from NCCS, Pune, and maintained in DMEM medium containing 10\% FBS and 1\% PSA mix. The cells were cultured in $\mathrm{CO}_{2}$ incubator at $5 \% \mathrm{CO}_{2}$ and $95 \%$ relative humidity.

\section{In vitro cell viability assay}

Mitochondrial reduction assay (3-(4,5-dimethylthiazol-2-yl)-2,5diphenyltetrazolium bromide) was performed to evaluate the cytotoxic activity of the extract against cervical cancer cell line (HeLa). Monolayer of the HeLa cell lines was trypsinized using Dulbecco's trypsin EDTA solution. The trypsinized cells were washed in PBS and the cells were counted manually using the hemocytometer. Approximately $1 \times$ $10^{6}$ cells $(100 \mu \mathrm{L})$ were seeded on to the 96 -well poly-L-lysine coated plate and the plate was incubated at $37^{\circ} \mathrm{C}$ under $5 \% \mathrm{CO}_{2}$ for $24 \mathrm{~h}$. After $24 \mathrm{~h}$, the cells were replaced with fresh medium and $50 \mu \mathrm{L}$ of extract was prepared in DMSO at different concentrations $(20,40,60,80$, and $100 \mu \mathrm{g} / \mathrm{mL}$ ) were added to the wells. The plates were incubated for $48 \mathrm{~h}$ at $37^{\circ} \mathrm{C}$ in a humidified $\mathrm{CO}_{2}$ incubator. After $48 \mathrm{~h}$, medium was removed and $30 \mu \mathrm{L}$ of $0.5 \% \mathrm{w} / \mathrm{v}$ of MTT was added and incubated at room temperature for $4 \mathrm{~h}$, the reaction was stopped by the addition of $50 \mu \mathrm{L}$ of acid - isopropanol to dissolve the formazan crystals and incubated for $30 \mathrm{~min}$ in room temperature, and the absorbance was taken at $570 \mathrm{~nm}$ in ELISA microtiter plate reader (BioRad). The assay was performed in triplicates. Colchicine $(1 \mu \mathrm{g} / \mathrm{mL})$ was used as the positive control.

\section{RESULTS AND DISCUSSION}

Radical scavenging activity of combined crude extract of $F$, religiosa and $\boldsymbol{F}$ benghalensis

Methanol extract of $F$. religiosa and $F$. benghalensis together was evaluated for their antioxidant potential using DPPH and hydrogen peroxide assay. DPPH assay is considered as a simple and convenient method to screen the antioxidant potential of the extracts irrespective of the solvents used to prepare the extracts $[13,14]$. Earlier reports have suggested that antioxidant activity (DPPH assay) of $F$. benghalensis is low compared to other Ficus sp. such as F. elastistica (Hawary et al., 2012) and the antioxidant potential of ethanolic extract of $F$. religiosa increased in percentage of cell inhibition with increase in concentration (Bhalerao and Sharma, 2014). The DPPH results from Fig. 1 show that of the concentrations chosen $20 \mu \mathrm{g} / \mathrm{mL}$ shows low scavenging activity, and the scavenging activity increases with the increase in concentration. Phenolic compounds, anthocyanins, and other natural compounds in crude plant crude extract can be investigated using DPPH assay (Chang et al., 2007).

Permeability of hydrogen peroxide across the cell membranes is considered a reason for the toxicity of this weak oxidizing agent. Hence, the scavenging activity of the extract to be considered for future pharmaceutical research is to be evaluated using the standard procedure (Kumaran et al., 2007). The $\mathrm{IC}_{50}$ value of the extract was $49.85 \mu \mathrm{g} / \mathrm{mL}$ compared to that of standard at $80.09 \mu \mathrm{g} / \mathrm{mL}$ (Table 1). The scavenging activity of the methanol extract of $F$. religiosa and $F$. benghalensis on the hydrogen peroxide is shown in Fig. 2. The results prove that the activity is dose dependent.

Phytochemical constituents of combined crude extract of $F$ religiosa and $F$, benghalensis leaves

The combined crude methanolic extract of $F$. religiosa and $F$. benghalensis showed nine peaks in GC-MS chromatogram based on their retention

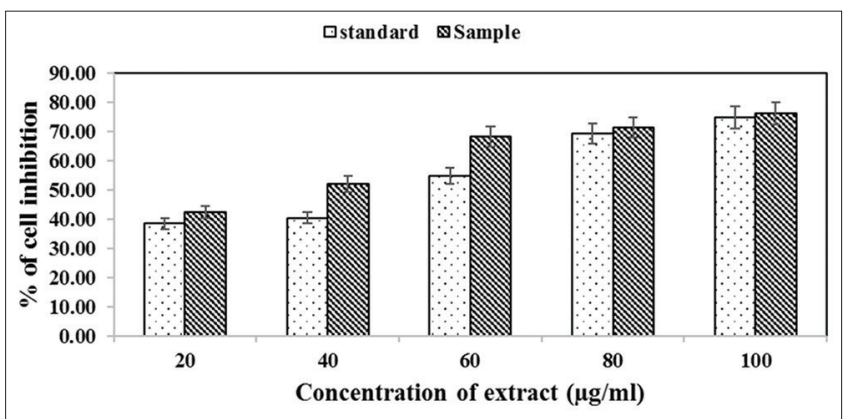

Fig. 1: Free radical scavenging activity of Ficus religiosa and Ficus benghalensis using 2, 2-diphenyl-1-picryl-hydrazyl-hydrate assay

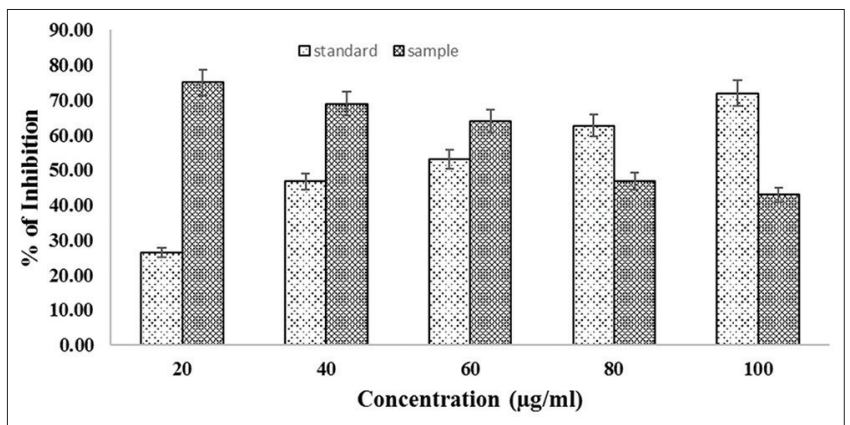

Fig. 2: Free radical scavenging activity of Ficus religiosa and Ficus benghalensis using $\mathrm{H}_{2} \mathrm{O}_{2}$ assay 
time. These compounds mainly comprised aldehyde, amine, acid, and aromatic groups (Table 2). Squalene compounds are identified in the peak of $24.67 \%$, amyrin acetate is identified in the peak of $28.90 \%$. The highest retention time was observed in peak of $29.41 \%$ with the compound [6-hydroxy-2, 2, 6-trimethyl-3-(3-methylbut-2-en-1-yl) cyclohexyl]methyl acetate followed by LUB-20(29)-en-3-ol, acetate, (3. beta.)- observed at peak of $30.089 \%$ (Fig. 3).

The presence of polyphenols such as aldehydes, acids, amine, and aromatic groups which are confirmed from the present GC-MS analysis and these polyphenols have exhibited their potential as an antioxidant, anti-inflammatory, antimicrobial, antidiabetic, hepatoprotective anticancer property, etc. [15]. The presence of polyphenol dichloroacetic acid, control the growth of tumor cells by depolarizing, thereby inducing apoptosis in glioblastoma cancer cells [16]. Heptadecenal plays a very important role in membrane stability, thereby inducing apoptosis in cancer cells. These phytoconstituent heptadecenal is reported to exhibit antioxidant and anticancer property [17].

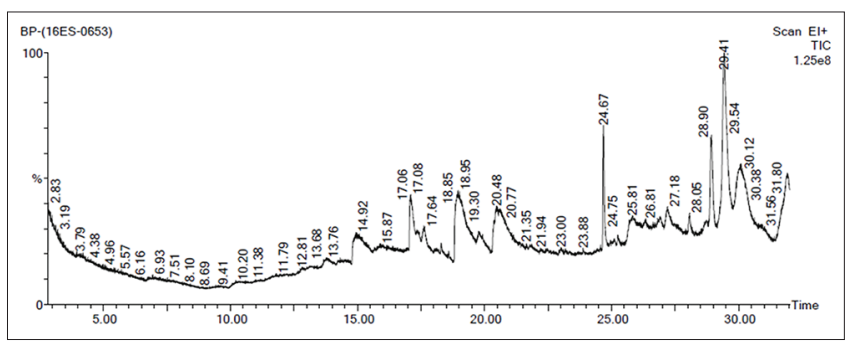

Fig. 3: A typical chromatogram of combined crude methanol extract of Ficus religiosa and Ficus benghalensis leaves
Cell viability assay of combined crude extract of $F$ religiosa and F benghalensis leaves

The methanol extract of leaves of $F$. religiosa and $F$. benghalensis was added to the HeLa cell lines after $24 \mathrm{~h}$ at different concentrations. After $48 \mathrm{~h}$ of incubation, the readings were observed at $570 \mathrm{~nm}$ in triplicates. The increased cell toxicity in the methanol concentration of $100 \mu \mathrm{g} /$ $\mathrm{mL}$ which is the highest concentration compared to the $20 \mu \mathrm{g} / \mathrm{mL}$. The results of Fig. 4 show a change in morphology of the cells at higher concentration and no significant change at lower concentrations of 20-60 $\mu \mathrm{g} / \mathrm{mL}$. The methanol extract of leaves Ficus elastica showed that increased cytotoxic activity against hepatocellular human tumor cell line (HepG2) and human breast cancer cell line (MCF-7), while a reduced or decreased cytotoxicity was observed by the leave extract of $F$. benghalensis comparatively (Hawary et al., 2012). Increase in concentration of extract decrease the rate of cell proliferation was obtained from results of Pitella et al., 2009, an extract of Centella asiatica.

The cell viability of the cells decreased with the increase in concentration, i.e. at $100 \mu \mathrm{g} / \mathrm{mL}$ concentration, only $50 \%$ of the cells were viable which is shown in Fig. 5. The cell viability was studied based on the GraphPad Prism software and the readings were taken in triplicates. These results are in agreement with the Hawary et al., 2012, in their study on the leaves of F. elastica and F. benghalensis, the lethal concentration was found to be at 121.2 and 149.7 against HepG-2 and MCF-7 cell line, respectively.

\section{CONCLUSION}

The results of the present investigation prove the possible synergistic activity of leaves of $F$. religiosa and $F$. benghalensis against cancer which in future can be evaluated further in animal models for a possible and an

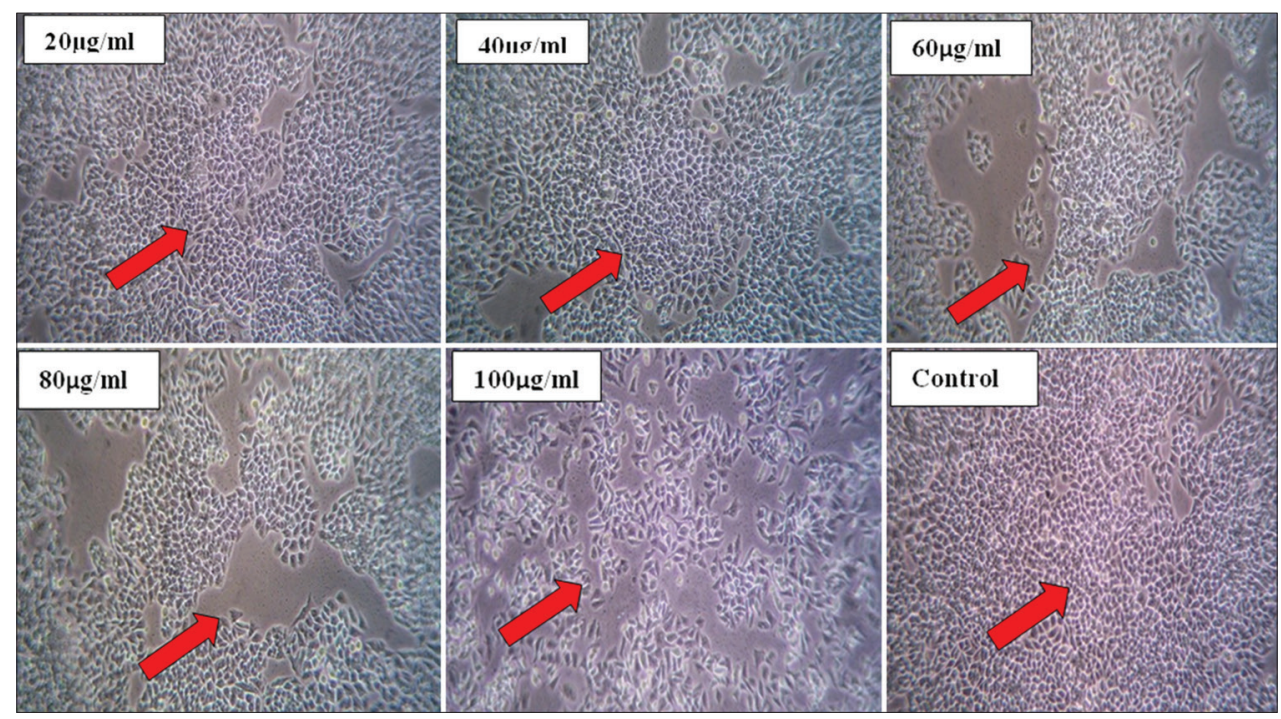

Fig. 4: Cell proliferation activity of the extract at different concentration against HeLa cell line

Table 1: $\mathrm{IC}_{50}$ value of the extract of $\boldsymbol{F}$. religiosa and $\boldsymbol{F}$. benghalensis using hydrogen peroxide assay

\begin{tabular}{|c|c|c|c|}
\hline \multirow[t]{2}{*}{ Concentration $(\mu \mathrm{g} / \mathrm{mL})$} & \multicolumn{3}{|c|}{ Hydrogen peroxide assay ( $\%$ of inhibition) } \\
\hline & Standard (ascorbic acid) & Combined leaf extract & IC $_{50}$ of combined leaf extract \\
\hline 20 & 26.52 & 75.00 & 24.26 \\
\hline 40 & 46.72 & 68.94 & 38.38 \\
\hline 60 & 53.16 & 64.02 & $49.85^{* *}$ \\
\hline 80 & 62.63 & $46.84^{* *}$ & 89.85 \\
\hline 100 & 71.97 & 42.93 & $98.97 * *$ \\
\hline
\end{tabular}

${ }^{* *} \mathrm{p}<0.01$. F. benghalensis: Ficus benghalensis, F. religiosa: Ficus religiosa 
Table 2: Bioactive compounds in combined leaves extract of $F$, religiosa and $F$ benghalensis

\begin{tabular}{|c|c|c|c|c|c|}
\hline Peak & Retention time (s) & Area \% & Chemical formula & Mol. weight (g/mol) & Name of the compound \\
\hline 1 & 2.828 & 43.004 & $\mathrm{CH}_{2} \mathrm{O}_{2} \mathrm{C}_{12}$ & 128 & DCA \\
\hline 2 & 14.978 & 4.651 & $\mathrm{C}_{14} \mathrm{H}_{26}^{2} \mathrm{O}_{8}$ & 322 & D-galactitol, 1,3,4,5-tetra-o-methyl-, Diacetate \\
\hline 3 & 17.094 & 3.815 & $\mathrm{C}_{17}^{14} \mathrm{H}_{32}^{26} \mathrm{O}$ & 252 & 16-Heptadecenal \\
\hline 4 & 18.945 & 10.788 & $\mathrm{C}_{16} \mathrm{H}_{32}^{32} \mathrm{O}_{2}$ & 256 & n-Hexadecanoic acid \\
\hline 5 & 20.476 & 7.013 & $\mathrm{C}_{24}{ }^{10} \mathrm{H}_{42}^{32} \mathrm{O}_{4}$ & 394 & Fumaric acid, Hexyl tetradec-3-enyl ester \\
\hline 6 & 24.672 & 2.659 & $\mathrm{C}_{30}^{24} \mathrm{H}_{50}^{42}$ & 410 & $\begin{array}{l}\text { 2,6,10,14,18,22-tetracosahexane, } \\
\text { 2,6,10,15,19,23-hexamethyl-(All-E-)- }\end{array}$ \\
\hline 8 & 29.419 & 14.330 & $\mathrm{C}_{17} \mathrm{H}_{30} \mathrm{O}_{3}$ & 282 & $\begin{array}{l}\text { [6-hydroxy-2,2,6-trimethyl-3-(3-methylbut-2-en-1-yl) } \\
\text { cyclohexyl] methyl acetate }\end{array}$ \\
\hline 9 & 30.089 & 10.062 & $\mathrm{C}_{32} \mathrm{H}_{52} \mathrm{O}_{2}$ & 468 & LUB-20 (29)-en-3-ol, acetate, (3. beta.)- \\
\hline
\end{tabular}

F. religiosa: Ficus religiosa, F. benghalensis: Ficus benghalensis, DCA: Dichloroacetic acid

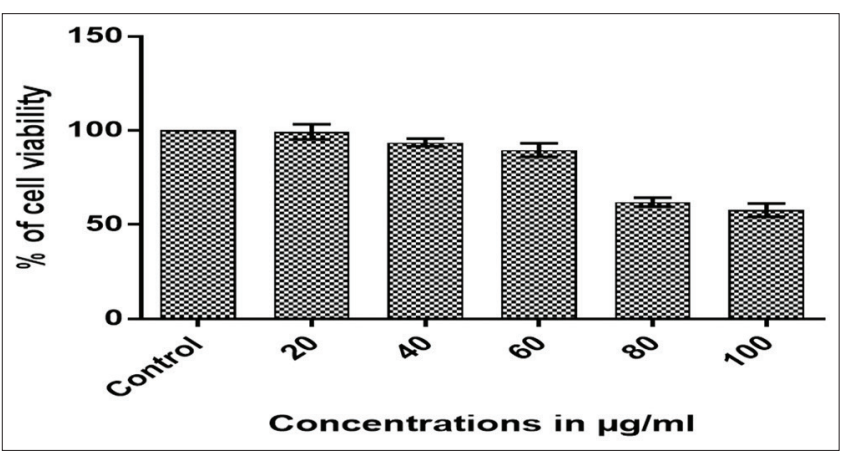

Fig. 5: Percentage of cell viability of the extract at different concentration against HeLa cells

effective drug against human cervical cancer. Further investigation is to be undertaken to identify and study the possible compound responsible for anticancerous activity of the extract.

\section{AUTHORS' CONTRIBUTION}

All authors have an equal contribution.

\section{CONFLICTS OF INTEREST}

The authors state "no conflict of interest" in the present research.

\section{REFERENCES}

1. Ramirez R, Carracedo J, Jimenez R, Canela A, Herrera E, Aljama P, et al. Massive telomere loss is an early event of DNA damaged-induced apoptosis. J Biol Chem 2003;278:836-42.

2. Newman DJ, Cragg GM. Natural products as sources of new drugs over the 30 years from 1981 to 2010. J Natl Prod 2012;75:311-35.

3. Newman DJ, Cragg GM, Snader KM. Natural products as sources of new drugs over the period 1981-2002. J Natl Prod 2003;66:1022-37.

4. Yang CS, Landaa JM, Huang MT, Newmark HL. Inhibition of carcinogenesis by dietary polyphenolic compound. Annu Rev Nutr 2001;21:381.

5. Swaminathan C. Phytochemical analysis and antibacterial and antioxidant properties of Indigofera tinctoria 1. Asian J Pharm Clin Res 2018;11:136-8.

6. Yang CS, Lambert JD. Shengmin sang antioxidative and anticarcinogenicactivities of tea polyphenols. Arch Toxicol 2009;83:11-21.

7. Ohba Y, Todo Y, Kobayashi N, Kaneuchi M, Watari H, Takeda M, et al. Risk factors for lower-limb lymphedema after surgery for cervical cancer. Int J Clin Oncol 2011;16:238-43.

8. Decaudin D, Marzo I, Brenner C, Kroemer G. Mitochondria in chemotherapy-induced apoptosis: A prospective novel target of cancer therapy. Int J Oncol 1998;12:141-52.

9. Chiranthanut N, Teekachunhatean S, Panthong A, Khonsung P, Kanjanapothi D, Lertprasertsuk N. Toxicity evaluation of standardized extract of Gynostemma pentaphyllum Makino. J Ethnopharmacol 2013;149:228-34.

10. Duguid JP, Marmion BP, Swain RH. Mackie and Mc Cartney Medical Microbiology. Vol. 1. Microbial Infections. $13^{\text {th }}$ ed. Edinburgh, Scotland: Churchill Livingstone; 1980. p. 304.

11. Kalpana G, Rishi RB. Ethnomedicinal knowledge and healthcare practices among the Tharus of Nwwalparasi district Incentral Nepal. For Ecol Manage 2009;257:2066-72.

12. Uddin SJ, Grice ID, Tiralongo E. Cytotoxic effects of Bangladeshi medicinal plant extracts. Evid Based Complementary Altern Med 2011;2011:1-7

13. Koleva II, van Beek TA, Linssen JP, de Groot A, Evstatieva LN. Screening of plant extracts for antioxidant activity: A comparative study on three testing methods. Phytochem Anal 2002;13:8-17.

14. Robinson JP, Kumaresan S, Ramasamy S, Ponnusamy P. Antioxidant and cytotoxic activity of Tecoma stans against lung cancer cell line (A549). Braz J Pharm Sci 2017;53:1-5.

15. Kumar S, Pandey AK. Chemistry and biological activities of flavonoids: An overview. Sci World J 2013;2013:1-16.

16. Michelakis ED, Sutendra G, Dromparis P, Webster L, Haromy A, Niven E, et al. Metabolic modulation of glioblastoma with dichloroacetate. Sci Transl Med 2010;2:31-4.

17. Parveen S, Shahzad A, Upadhyay A, Yadav V. Gas chromatographymass spectrometry analysis of methanolic leaf extract of Cassia angustifolia vahl. Asian J Pharm Clin Res 2016;9:111-6. 